\title{
Potassium Channelopathies and Gastrointestinal Ulceration
}

\author{
Jaeyong Han $^{1}$, Seung Hun Lee ${ }^{2}$, Gerhard Giebisch ${ }^{1}$, and Tong Wang ${ }^{1}$ \\ Departments of ${ }^{1}$ Cellular and Molecular Physiology and ${ }^{2}$ Internal Medicine, Section of Nephrology, Yale University, New Haven, CT, USA
}

Potassium channels and transporters maintain potassium homeostasis and play significant roles in several different biological actions via potassium ion regulation. In previous decades, the key revelations that potassium channels and transporters are involved in the production of gastric acid and the regulation of secretion in the stomach have been recognized. Drugs used to treat peptic ulceration are often potassium transporter inhibitors. It has also been reported that potassium channels are involved in ulcerative colitis. Direct toxicity to the intestines from nonsteroidal anti-inflammatory drugs has been associated with altered potassium channel activities. Several reports have indicated that the longterm use of the antianginal drug Nicorandil, an adenosine triphosphate-sensitive potassium channel opener, increases the chances of ulceration and perforation from the oral to anal regions throughout the gastrointestinal (GI) tract. Several of these drug features provide further insights into the role of potassium channels in the occurrence of ulceration in the Gl tract. The purpose of this review is to investigate whether potassium channelopathies are involved in the mechanisms responsible for ulceration that occurs throughout the Gl tract.

(Gut Liver 2016;10:881-889)

Key Words: Gastrointestinal tract; Ulceration; Potassium channels; $\mathrm{H}^{+} / \mathrm{K}^{+}$-ATPase

\section{INTRODUCTION}

Potassium $\left(\mathrm{K}^{+}\right)$homeostasis involves the maintenance of the total body potassium content and plasma potassium levels at steady-state. It includes external $\mathrm{K}^{+}$balance between dietary $\mathrm{K}^{+}$ intake and $\mathrm{K}^{+}$excretion, and internal $\mathrm{K}^{+}$balance between intracellular and extracellular compartments. ${ }^{1}$ Normally, people ingest about $100 \mathrm{mmol} /$ day of $\mathrm{K}^{+}$in their diets; they absorb about $90 \%$ of the $\mathrm{K}^{+}$intake and excrete an equivalent amount of $\mathrm{K}^{+}$
(90 mmol/day) in the urine. Normal fecal $\mathrm{K}^{+}$excretion averages about $10 \mathrm{mmol} /$ day. More than $98 \%$ of potassium ions are intracellular, and only about $70 \mathrm{mmol}(2 \%)$ are in the extracellular fluid. Factors that can alter potassium distribution between the intracellular and extracellular fluid are insulin, aldosterone, $\beta$-adrenergic stimulation, acidosis and alkalosis, cell lysis, and extracellular fluid osmolarity. ${ }^{2}$ Potassium constitutes the main intracellular electrolyte and osmolyte for fundamental processes such as membrane excitability, ion and solute transport or cell volume regulation. If intracellular and extracellular potassium levels are not properly maintained, it may lead to growth retardation, muscle weakness, and cardiac arrhythmia in a clinical setting. Potassium level is mainly regulated by the kidney. Both external and internal potassium homeostasis are largely maintained by potassium channels and transporters. ${ }^{3}$ They participate in the resting cellular-membrane potential and the propagation of action potential along with systemic blood-pressure control, vascular tone, gastrointestinal (GI) motility, glucose and insulin metabolism, mineralocorticoid action, acid-base balance, renal concentrating ability, and fluid and electrolyte balance. ${ }^{4}$ For example, an anomaly of a voltage-gated potassium channel can provoke congenital long QT syndrome, while a defect in the adenosine triphosphate (ATP)-sensitive potassium channel can provoke Bartter's syndrome. ${ }^{5,6}$

Potassium channels represent the largest and most heterogeneous family of ion channels. In addition to trans-epithelial transport, various $\mathrm{K}^{+}$channels are involved in cell volume regulation, differentiation, migration, apoptosis, and carcinogenesis. ${ }^{7}$ $\mathrm{K}^{+}$channels consist of a primary pore-forming $\alpha$-subunit often associated with regulatory $\beta$-subunits. In the human genome, there are more than 70 genes coding for $\alpha$-subunit of $\mathrm{K}^{+}$channels. Potassium channels are named by using the HUGO Gene Nomenclature Committee nomenclature. ${ }^{8}$ They are classified into four families: calcium-activated $\left(\mathrm{K}_{\mathrm{ca}}\right)$, inwardly rectifying $\left(\mathrm{K}_{\mathrm{ir}}\right)$, voltage-gated $\left(\mathrm{K}_{\mathrm{v}}\right)$, and two-pore $\left(\mathrm{K}_{2 \mathrm{p}}\right) \mathrm{K}^{+}$channels.

Correspondence to: Tong Wang

Department of Cellular and Molecular Physiology, Yale School of Medicine, 333 Cedar Street, P.0. Box 208026, New Haven, CT 06520-8026, USA

Tel: +1-203-785-6435, Fax: +1-203-785-4951, E-mail: tong.wang@yale.edu

Received on August 25, 2015. Revised on October 14, 2015. Accepted on October 20, 2015.

pISSN 1976-2283 eISSN 2005-1212 https://doi.org/10.5009/gnl15414

@ This is an Open Access article distributed under the terms of the Creative Commons Attribution Non-Commercial License (http://creativecommons.org/licenses/by-nc/4.0) which permits unrestricted non-commercial use, distribution, and reproduction in any medium, provided the original work is properly cited. 


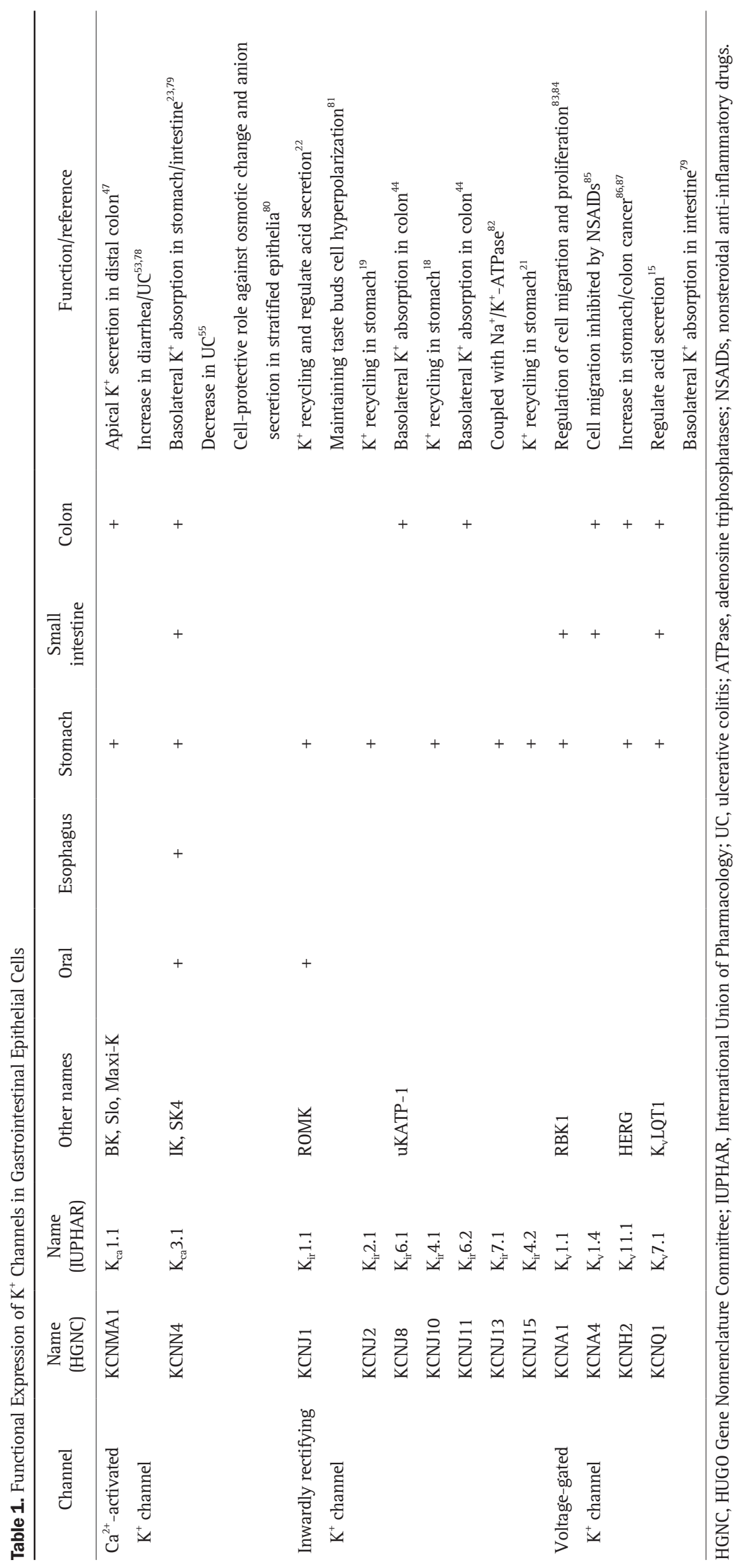


Transporters usually carry multiple ions at the same time while channels carry only a single ion. There are two P-type adenosine triphosphatases (ATPase) transporters: $\mathrm{Na}^{+} / \mathrm{K}^{+}$-ATPase and $\mathrm{H}^{+} / \mathrm{K}^{+}$-ATPase, along with an one of solute carrier (SLC) family: $\mathrm{Na}^{+} / \mathrm{K}^{+} / 2 \mathrm{Cl}^{-}$cotransporter (NKCC1). ${ }^{9}$

There has been a recent resurgence of interest in the area of GI motility, with reports that potassium channels in epithelial cells of the GI system also participate in external $\mathrm{K}^{+}$balance. The function of these channels has not been well defined. Physiologically, potassium channels and transporters are involved in producing gastric acid and secreting in the stomach, and play roles in the absorptive and secretory pathways of potassium in the intestine. The function of $\mathrm{K}^{+}$channels expressed in GI epithelial cells is described in Table 1 . This commentary summarizes the available information of $\mathrm{K}^{+}$channel expression and function in GI epithelial cells, and the relation of $\mathrm{K}^{+}$channels to the mechanism of GI ulceration.

\section{$\mathrm{K}^{+}$CHANNEL AND GASTRIC SECRETION}

In the stomach mucosa, acid secretion occurs in a specialized cell type, the parietal cell. The acid producing enzyme $\mathrm{H}^{+} / \mathrm{K}^{+}-$ ATPase (or proton pump) is an essential transporter involved in the final pathway of gastric acid secretion. ${ }^{10,11}$ This enzyme pumps $\mathrm{H}^{+}$into the lumen in exchange for $\mathrm{K}^{+}$. In the resting state, proton pump is localized mainly in the cytoplasmic tubulovesicles below the plasma membrane. When gastric acid stimulants such as gastrin, histamine, or acetylcholine activate the parietal cell, the tubulovesicles move to and fuse with the apical secretory canaliculi, leading to expand the area of the canaliculi and increase gastric acid secretion. ${ }^{12}$ The half-life of gastric $\mathrm{H}^{+} /$ $\mathrm{K}^{+}$-ATPase lasts for 50 hours, hence about $25 \%$ of pumps are synthesized per day. ${ }^{13}$

Gastric $\mathrm{H}^{+} / \mathrm{K}^{+}$-ATPase pump protons into the luminal space leading to more than one million-fold higher concentration of $\mathrm{H}^{+}$in the gastric juice. Therefore, tubulovesicular $\mathrm{K}^{+}$recycling pathway for $\mathrm{K}^{+}$supply is required for avoiding $\mathrm{K}^{+}$depletion of luminal fluid (Fig. 1). Although postulated for several years, it has a long time to determine the presence of such $\mathrm{K}^{+}$recycling pathway in the gastric parietal cell. In KCNQ1 $\left(\mathrm{K}_{\mathrm{v}} 7.1\right)$ knockout mice, which has been related with "Long QT Syndrome Type I", an unexpected stomach hyperplasia has been observed in $2000 .^{14}$ Soon after the description of the gastric phenotype of KCNQ1 knockout mice, a couple of groups reported that the expression of KCNQ1 channel is abundantly expressed in human and mouse gastric mucosa. ${ }^{15,16}$

There have been reliable evidences for a role of KCNQ1 in acid secretion of parietal cells, but not all $\mathrm{H}^{+} / \mathrm{K}^{+}$-ATPase-positive parietal cells show strong KCNQ1 expression. The exact localization and trafficking of these channels has remained obscure, and no evidence has been found for apical trafficking of these channels during acid secretion. ${ }^{17}$ Proton secretion was found to be suppressed by Barium, a nonspecific blocker of inwardly rectifying $\mathrm{K}^{+}$channels. Localization and genomic studies have provided evidence for the presence of inward-rectifier $\mathrm{K}^{+}$channels; KCNJ10 $\left(\mathrm{K}_{\mathrm{ir}} 4.1\right)$ is localized at the apical microvilli of the parietal cell. ${ }^{18}$ Likewise $\mathrm{KCNJ} 2\left(\mathrm{~K}_{\mathrm{ir}} 2.1\right)$ has been proposed as another luminal $\mathrm{K}^{+}$channel in rabbit parietal cell. ${ }^{19}$ Trafficking of enhanced green fluorescent protein (EGFP)-tagged KCNJ10 $\left(\mathrm{K}_{\mathrm{ir}} 4.1\right)$ channels in parietal cells shows KCNJ10 translocation to the apical secretory membrane after stimulation. ${ }^{20}$ KCNJ15 $\left(\mathrm{K}_{\mathrm{ir}} 4.2\right)$ is also reported in $\mathrm{H}^{+} / \mathrm{K}^{+}$-ATPase-enriched tubulovesicles and translocation to the apical membrane. ${ }^{21}$ Recently ATPsensitive KCNJ1 ( $\mathrm{K}_{\mathrm{ir}} 1.1$; ROMK) colocalized with the $\beta$-subunit

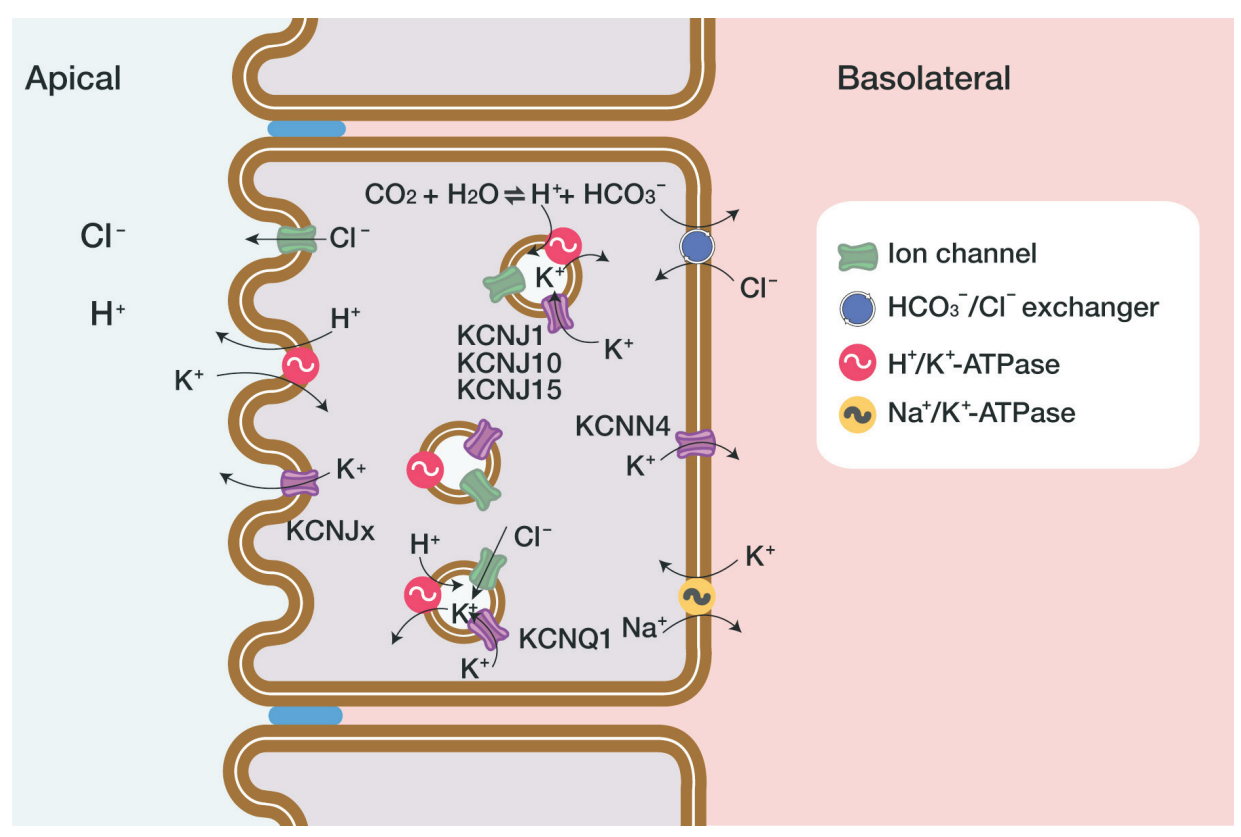

Fig. 1. Gastric acid secretion and $\mathrm{K}^{+}$channels in a parietal cell of the stomach. Acid is produced from the hydration of $\mathrm{CO}_{2}$ to form $\mathrm{H}^{+}$and $\mathrm{HCO}_{3}^{-}$. Apical and tubulovesicular $\mathrm{K}^{+}$channels provide $\mathrm{K}^{+}$recycling, which is required for the function of the proton pump, $\mathrm{H}^{+} / \mathrm{K}^{+}$-ATPase. 
of $\mathrm{H}^{+} / \mathrm{K}^{+}$-ATPase in gastric parietal cells of wild-type mice, and $\mathrm{K}_{\mathrm{ir}}$ 1.1-deficient mice show a defect in secretagogue-induced acid secretion in gastric glands. ${ }^{22}$ It has been shown that KCNN4 $\left(\mathrm{K}_{\mathrm{ca}} 3.1\right)$ is expressed in the basolateral membrane of parietal cell. $^{23}$

Inwardly rectifying $\mathrm{K}^{+}$channels and KCNQ1 work together in potassium recycling across the apical pole of parietal cells. The statement that the correlation between $\mathrm{K}^{+}$channels and gastric acid secretion by "No Potassium, No Acid" is open to question. ${ }^{24}$ However, the mechanisms of $\mathrm{K}^{+}$dependent acid secretion in the stomach are still under investigation.

As shown in Fig. 1, concurrently with $\mathrm{H}^{+}, \mathrm{Cl}^{-}$extruded across the apical membrane via the different types of $\mathrm{Cl}^{-}$channels, the cystic fibrosis transmembrane regulator and SLC26A9, contribute to electroneutral net $\mathrm{HCl}$ secretion. ${ }^{25,26}$

Identification of the proton pump, $\mathrm{H}^{+} / \mathrm{K}^{+}$-ATPase, as the final step of gastric acid secretion provides an opportunity to develop a new class drug, a proton pump inhibitor (PPI). Omeprazole was discovered by a Swedish research group in $1981 .{ }^{27}$ Later on, lansoprazole, pantoprazole, and rabeprazole were subsequently developed. PPIs are widely used in the treatment of peptic ulcer disease and gastroesophageal reflux disease (GERD). They are weak-base prodrugs that accumulate and activate in the gastric parietal cell. Once activated within the parietal cell canaliculus, the PPI binds irreversibly with activated $\mathrm{H}^{+} / \mathrm{K}^{+}$-ATPase, resulting in the inhibition of gastric acid secretion. ${ }^{28}$ Thus the inhibition is long-lasting with no tolerance. However, they have a short plasma half-life of about 2 hours and bind only to activated $\mathrm{H}^{+}$/ $\mathrm{K}^{+}$-ATPase, so it takes 4 to 5 days to achieve maximal acid suppression at therapeutic doses. $^{29}$

On the contrary, the potassium-competitive acid blockers (P-CABs) reversibly inhibit acid secretion by competing with potassium on the luminal surface of the gastric $\mathrm{H}^{+} / \mathrm{K}^{+}$-ATPase. ${ }^{30}$ The first developed compound was SCH28080 in 1982. ${ }^{31}$ BY841, AZD0865, soraprazan (BY359), and several other P-CABs were subsequently developed. Animal and early clinical studies have demonstrated that $\mathrm{P}-\mathrm{CABs}$ are highly selective for gastric $\mathrm{H}^{+} /$ $\mathrm{K}^{+}$-ATPase and inhibit gastric acid secretion with fast onset of action. $^{32}$ SCH28080 has been used extensively to explore the mechanism of inhibition of the proton pump. ${ }^{33,34}$ The first generation drugs were not released due to their brevity of action and hepatotoxicity. ${ }^{35}$ New P-CAB drugs, revaprazan (YH1885) and Vonoprazan (TAK-438) that overcome these shortcomings were recently launched. ${ }^{36,37}$ These drugs are highly selective and slower dissociation for gastric $\mathrm{H}^{+} / \mathrm{K}^{+}$-ATPase. Vonoprazan is not inferior to lansoprazole in the treatment of peptic ulcer disease and GERD, rather superior for eradication of Helicobacter pylori infection.

\section{$\mathrm{K}^{+}$CHANNEL IN COLONIC $\mathrm{K}^{+}$HANDLING}

Under normal circumstances, the kidneys maintain potassium homeostasis simply by matching excretion with dietary potassium intake, and the colon also plays a minor role in potassium excretion. The colon have the function of active potassium secretion and absorption. In patients with end-stage renal disease, colonic $\mathrm{K}^{+}$secretion is believed to become a main determinant of $\mathrm{K}^{+}$homeostasis. In extreme forms of secretory diarrhea like cholera, it is common to lose more than $5 \mathrm{~L}$ of water with a $\mathrm{K}^{+}$ loss of 100 to $200 \mathrm{mmol} / \mathrm{day}^{38}$

One important aspect of $\mathrm{K}^{+}$transport in the mammalian colon is in its segmental difference. Under normal conditions, the proximal colon shows net $\mathrm{K}^{+}$secretion while the distal colon performs net $\mathrm{K}^{+}$absorption. ${ }^{39}$ Active $\mathrm{K}^{+}$absorption in the mammalian distal colon is conducted by nongastric $\mathrm{H}^{+} / \mathrm{K}^{+}$-ATPase $\left(\mathrm{HK}_{\alpha 2}\right)$ in luminal membrane. ${ }^{40}$ The colonic $\mathrm{H}^{+} / \mathrm{K}^{+}$-ATPase $\left(\mathrm{HK}_{\alpha 2}\right)$ is partially blocked by ouabain but not with omeprazole and $\mathrm{SCH} 28080 .{ }^{41}$ For evaluation of the functional role of $\mathrm{HK}_{\alpha 2}$ in intestinal $\mathrm{K}^{+}$handling, $\mathrm{HK}_{\alpha 2}$ knockout mice were used. On a normal diet, these mice sustain a normal $\mathrm{K}^{+}$homeostasis even though they have a slightly increase of fecal $\mathrm{K}^{+}$excretion. These mice do, however, develop profound hypokalemia on a $\mathrm{K}^{+}$free diet. ${ }^{42}$ During $\mathrm{K}^{+}$deprivation, colonic $\mathrm{HK}_{\alpha 2}$ plays a critical role in the maintenance of $\mathrm{K}^{+}$homeostasis. KCNQ1 is located in basolateral membrane for active $\mathrm{K}^{+}$absorption. ${ }^{43}$ Recently, ATP-sensitive inwardly rectifying $\mathrm{K}^{+}$channels KCNJ8 $\left(\mathrm{K}_{\mathrm{ir}} 6.1\right)$, $\mathrm{KCNJ} 11\left(\mathrm{~K}_{\mathrm{ir}} 6.2\right)$ and regulatory sulfonylurea receptor subunits were discovered in rat distal colon. ${ }^{44}$

Net increase of $\mathrm{K}^{+}$secretion is seen in animals with ingestion of high $\mathrm{K}^{+}$diet both in the proximal colon and distal colon. ${ }^{45}$ It is assumed that $\mathrm{Ca}^{2+}$-activated $\mathrm{K}^{+}$channels in colon are involved in $\mathrm{K}^{+}$secretion. ${ }^{46}$ Convincing evidences from the study using the KCNMA1 $\left(\mathrm{K}_{\mathrm{ca}} 1.1\right.$; large conductance; BK) $\alpha$-subunitdeficient mouse show that this channel plays crucial role in $\mathrm{K}^{+}$ secretion in distal colon. ${ }^{47}$ It has been known that BK channels are responsible for resting and stimulated $\mathrm{Ca}^{2+}$-activated $\mathrm{K}^{+}$secretion in mouse distal colon. BK channels has been variously referred to as the maxi-K or Slo channel. Another $\mathrm{Ca}^{2+}$-activated intermediate conductance $\mathrm{K}^{+}$(IK) channel, referred as KCNN4 $\left(\mathrm{K}_{\mathrm{ca}} 3.1\right)$ splice variants were identified in rat colon. ${ }^{48} \mathrm{KCNN} 4 \mathrm{~b}$ and KCNN4c transcripts seems to encode basolateral and apical membrane proteins in distal colon, respectively. It is widely known aldosterone increases distal $\mathrm{K}^{+}$secretion in colon, which is mediated by the BK channel and KCNN4c. ${ }^{49}$ Basolateral uptake of $\mathrm{K}^{+}$via $\mathrm{Na}^{+} / \mathrm{K}^{+}$-ATPase and NKCC1 is required for active epithelial $\mathrm{K}^{+}$secretion. ${ }^{50}$ These findings explain distal colonic $\mathrm{K}^{+}$ handling (Fig. 2). $\mathrm{K}^{+}$channels which are related with $\mathrm{K}^{+}$secretion in the proximal colon also needs to be investigated. ${ }^{51}$

Many publications have shown that altered expression of BK channels maybe related with several conditions in intestinal disease. For example, in patients with severe diarrhea, large amounts of colonic $\mathrm{K}^{+}$secretion frequently cause hypokalemia. In these cases, BK channels play a major role in controlling $\mathrm{K}^{+}$secretion. ${ }^{52}$ Patients with severe ulcerative colitis (UC) often 


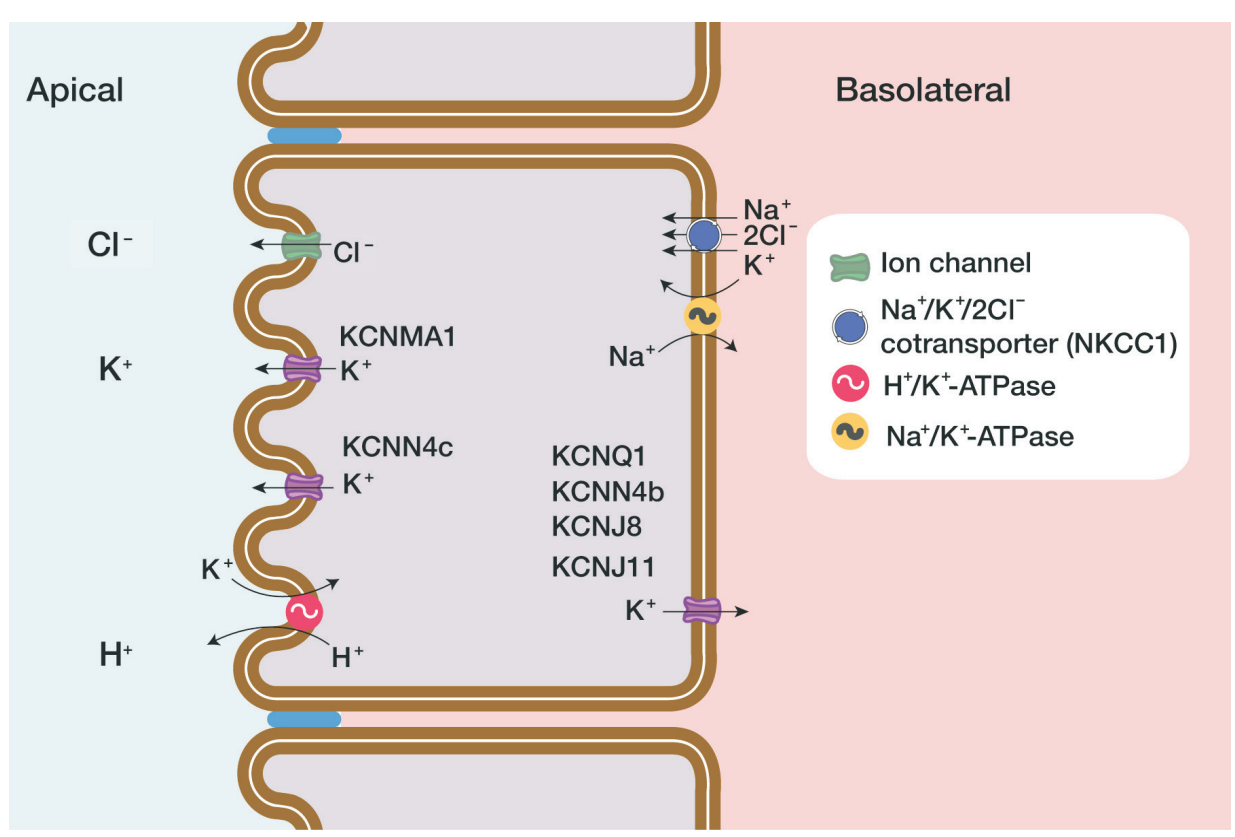

Fig. 2. $\mathrm{K}^{+}$absorption and secretion in an epithelial cell of the distal colon. $\mathrm{K}^{+}$absorption is mediated by an apical colonic $\mathrm{H}^{+} / \mathrm{K}^{+}$-ATPase followed by basolateral $\mathrm{K}^{+}$channels. $\mathrm{K}^{+}$secretion is mediated by the basolateral $\mathrm{Na}^{+} / \mathrm{K}^{+}$-ATPase and $\mathrm{Na}^{+} / \mathrm{K}^{+} / 2 \mathrm{Cl}^{-}$cotransporter (NKCC1) followed by the efflux of apical $\mathrm{K}^{+}$ channels. present hypokalemia. It has been reported the expression of BK channel is increased in patients with UC. ${ }^{53}$ In the dextran sulfate sodium (DSS)-induced colitis model, active $\mathrm{K}^{+}$secretion was observed this is thought to relate to the up-regulation of the apical BK channel that is expressed three times more than control, whereas $\mathrm{Cl}^{-}$secretion is diminished. ${ }^{54}$ On the other hand, the basolateral IK channel expression and activity are markedly decreased in active UC. ${ }^{55}$ These studies suggests a strong correlation between potassium channel expression and pathogenesis of diarrhea in UC.

\section{DRUG INFLUENCING $\mathrm{K}^{+}$CHANNELS AND NOTABLE UL- CERATION AS THEIR SIDE EFFECT}

It is widely known over the last 20 years that high $\mathrm{K}^{+}$intake increases the ATP-sensitive $\mathrm{K}^{+}$channel (such as ROMK) expression and activity in the kidney. ${ }^{56}$ However, whether increased $\mathrm{K}^{+}$channel activity causes ulceration in the GI tract is not clear. Several lines of evidence suggest that upregulation of the $\mathrm{K}^{+}$ channel may cause ulceration in the GI tract.

First, in the 1960s, the enteric coated potassium chloride tablet formulation was used in patients. During the use of this formulation, complicated cases were reported concerning the development of ulceration and perforation in the small intestine. ${ }^{57,58} \mathrm{~K}^{+}$supplements are selectively being used for patients with hypokalemia, and GI ulceration is intermittently reported in these patients with the use of $\mathrm{K}^{+}$supplements. ${ }^{59}$ From these cases, potassium ion itself proved to account for the development of a specific type of GI ulcer disease.

Second, it is presumed $\mathrm{K}^{+}$channels are regulated by some of the nonsteroidal anti-inflammatory drugs (NSAIDs). It is well established that NSAIDs is a common cause of GI ulceration. It is generally agreed that inhibition of prostaglandin (PG) synthesis by cyclooxygenase (COX) is the principal mode of the analgesic and anti-inflammatory actions. NSAIDs-induced mucosal injury mechanism has been described as impaired mucosal defense from decreased mucoprotective PG production. ${ }^{60}$ In addition, arachidonic acid metabolism is shifted to the alternative 5-lipoxygenase pathway which increases synthesis of leukotrienes by nonselective NSAIDs, ${ }^{61}$ and enhances the production of proinflammatory mediators such as tumor necrosis factor $\alpha$ $(\mathrm{TNF}-\alpha){ }^{62}$ Another mechanism of GI ulceration has been suggested, which is that NSAIDs have a direct cytotoxic effect on mucosal cell causing injury and damage. ${ }^{63}$ From one of these mechanism, a report shows that NSAIDs stimulate $\mathrm{K}^{+}$efflux and increase the permeability of cell membrane. ${ }^{64}$ Some of these NSAIDs have been also identified as openers of ATP-sensitive $\mathrm{K}^{+}\left(\mathrm{K}_{\text {ATP }}^{+}\right)$channels, members of the $\mathrm{K}_{\mathrm{ir}}$ family, which participate in the antinociception in both the central and the peripheral nervous system. ${ }^{65}$ Meanwhile Celecoxib, a selective inhibitor of COX-2, has been known to have no effect on mucoprotective PG synthesis. In recently reported research, Celecoxib can modulate several ion channels and alter functioning of neurons and myocytes at clinically relevant concentrations independent of COX inhibition. ${ }^{66}$ This drug inhibits many voltage-gated ion channels including KCNQ1 $\left(\mathrm{K}_{\mathrm{v}} 7.1\right)$ that are regulatory channels of gastric acid secretion. However, whether NSAIDs and/or inhibition of PG regulate $\mathrm{K}^{+}$channel expression and function in the GI system needs to be studied. A possible hypothesis to explain this side effect would be that the changes in the potassium channel in GI epithelial cells increase membrane permeability, which induces mucosal barrier defects and initiates ulceration.

Third, Nicorandil (2-nicotinamidoethyl-nitrate ester), which has been used clinically for as treatment for ischemic heart 
disease, possesses both nitrate-like and $\mathrm{K}_{\text {ATP }}^{+}$channel activating properties. ${ }^{67}$ The nitric oxide (NO)-like action leads to dilatation of the large coronary arteries, whereas the potassium channel opening leads to the peripheral vasodilator and reduces both preload and afterload. This NO plays a beneficial role in mucosal defense by modulating the mucosal circulation in the stomach. ${ }^{68}$ Headache has been a main adverse event associated with the use of nicorandil. The side effects of oral and anal ulceration have been intermittently reported, ${ }^{69,70}$ which involve ulcerations throughout the GI tract. ${ }^{71,72}$ Peristomal and vulvar ulcerations are also described. ${ }^{73,74}$ The chance of this rare but potentially severe side effect increases with higher doses and long term use of this drug, and heals after drug withdrawal. A recent population-based study of this drug's association with GI ulceration or perforation has been reported. ${ }^{75}$ This study, based on more than 600,000 randomly selected patients, found a $43 \%$ increase in the risk of GI ulceration and a 60\% increase in the risk of GI perforation. Therefore, patient history should be taken at the time of diagnosis of GI ulceration to determine whether the patient is taking nicorandil and/or NSAIDs.

There is, however, a conflicting report about $\mathrm{K}_{\text {ATP }}^{+}$channel. Diazoxide, which is known to be a $\mathrm{K}_{\text {ATP }}^{+}$channel opener, has been used to control hypertension. Interestingly, nicorandil and diazoxide are effective in healing of acute gastric injury in an animal model. ${ }^{76,77}$

All this information elaborates that altered potassium channel and development of ulceration in GI tract are closely related. In-depth research of potassium channels in GI tract will help to illustrate the common pathway in molecular mechanism of ulceration.

\section{CONCLUSIONS}

Several potassium channels and transporters have been known to play roles in gastric acid production and secretion in terms of "No potassium, No acid." Medications used for peptic ulcer disease often inhibit transporters of potassium. Potassium channels in small and large intestines have been studied to determine how they handle external $\mathrm{K}^{+}$balance. Interestingly, increased expression of the BK potassium channel and decreased expression of the IK potassium channel expression have been observed in active UC in humans. Increased expression of BK channel have also been found in a rodent model of DSS-induced colitis. The drug, which has an action similar to the ATP-sensitive potassium channel openers such as Nicorandil and some NSAIDs, increases the incidence of GI ulceration. Longer duration of the use of high-dose Nicorandil increases the chance of developing oral and anal ulcerations, GI ulceration, and perforation of the GI tract. To conclude, the high correlation between potassium channels and development of ulceration suggests the presence of a novel mechanism of GI ulceration which indicates a common pathway of all types of ulceration developing throughout the GI tract. Further study on potassium channels in the GI epithelial cells offers significant insight into a mechanism of GI ulceration and development of potential drug candidate.

\section{CONFLICTS OF INTEREST}

No potential conflict of interest relevant to this article was reported.

\section{ACKNOWLEDGEMENTS}

We especially thank Dr. John Geibel (Yale University) for his kind discussion about this review paper. This investigation was supported by Public Health Service Grants R01- DK099284 (Tong Wang and Lawrence Palmer) and P01 NIH/NIDDK, DK 17433 (Core E, Tong Wang) from the National Institute of Diabetes and Digestive and Kidney Diseases.

\section{REFERENCES}

1. Giebisch GH. A trail of research on potassium. Kidney Int 2002;62: 1498-1512.

2. Giebisch G, Windhager E. Transport of potassium. In: Boron WF, Boulpaep EL, eds. Medical physiology a cellular and molecular approach. 2nd ed. Philadelphia: Saunders Elsevier, 2012:821-834.

3. Sahni V, Gmurczyk A, Rosa RM. Extrarenal potassium metabolism. In: Alpern RJ, Moe 0, Caplan MJ, eds. Seldin and Giebisch's the kidney: physiology and pathophysiology. 5th ed. London: Academic Press, 2013:1629-1658.

4. Gumz ML, Rabinowitz L, Wingo CS. An integrated view of potassium homeostasis. N Engl J Med 2015;373:60-72.

5. Roden DM, Viswanathan PC. Genetics of acquired long QT syndrome. J Clin Invest 2005;115:2025-2032.

6. Amirlak I, Dawson KP. Bartter syndrome: an overview. QJM 2000;93:207-215.

7. Heitzmann D, Warth R. Physiology and pathophysiology of potassium channels in gastrointestinal epithelia. Physiol Rev 2008;88:1119-1182.

8. HUGO Gene Nomenclature Committee (HGNC). Gene family: potassium channels [Internet]. Cambridge: European Bioinformatics Institute; c2016 [cited 2015 Aug 25]. Available from: http://www. genenames.org/cgi-bin/genefamilies/set/183.

9. Alexander SP, Benson HE, Faccenda E, et al. The Concise Guide to PHARMACOLOGY 2013/14: transporters. Br J Pharmacol 2013; 170:1706-1796.

10. Ganser AL, Forte JG. K+-stimulated ATPase in purified microsomes of bullfrog oxyntic cells. Biochim Biophys Acta 1973;307:169-180.

11. Sachs G, Chang HH, Rabon E, Schackman R, Lewin M, Saccomani G. A nonelectrogenic H+ pump in plasma membranes of hog stomach. J Biol Chem 1976;251:7690-7698.

12. Athmann C, Zeng N, Scott DR, Sachs G. Regulation of parietal 
cell calcium signaling in gastric glands. Am J Physiol Gastrointest Liver Physiol 2000;279:G1048-G1058.

13. Gedda K, Scott D, Besancon M, Lorentzon P, Sachs G. Turnover of the gastric $\mathrm{H}+, \mathrm{K}(+)$-adenosine triphosphatase alpha subunit and its effect on inhibition of rat gastric acid secretion. Gastroenterology 1995;109:1134-1141.

14. Lee MP, Ravenel JD, Hu RJ, et al. Targeted disruption of the Kvlqt1 gene causes deafness and gastric hyperplasia in mice. J Clin Invest 2000;106:1447-1455.

15. Grahammer F, Herling AW, Lang HJ, et al. The cardiac K+ channel KCNQ1 is essential for gastric acid secretion. Gastroenterology 2001;120:1363-1371.

16. Dedek K, Waldegger S. Colocalization of KCNQ1/KCNE channel subunits in the mouse gastrointestinal tract. Pflugers Arch 2001;442:896-902.

17. Heitzmann D, Grahammer F, von Hahn T, et al. Heteromeric KCNE2/KCNQ1 potassium channels in the luminal membrane of gastric parietal cells. J Physiol 2004;561(Pt 2):547-557.

18. Fujita A, Horio Y, Higashi K, et al. Specific localization of an inwardly rectifying $\mathrm{K}(+)$ channel, Kir4.1, at the apical membrane of rat gastric parietal cells; its possible involvement in $\mathrm{K}(+)$ recycling for the $\mathrm{H}(+)-\mathrm{K}(+)-$ pump. J Physiol 2002;540(Pt 1):85-92.

19. Malinowska DH, Sherry AM, Tewari KP, Cuppoletti J. Gastric parietal cell secretory membrane contains PKA- and acid-activated Kir2.1 K+ channels. Am J Physiol Cell Physiol 2004;286:C495C506.

20. Kaufhold MA, Krabbenhöft A, Song P, et al. Localization, trafficking, and significance for acid secretion of parietal cell Kir4.1 and KCNQ1 K+ channels. Gastroenterology 2008;134:1058-1069.

21. He W, Liu W, Chew CS, et al. Acid secretion-associated translocation of KCNJ15 in gastric parietal cells. Am J Physiol Gastrointest Liver Physiol 2011;301:G591-G600.

22. Vucic E, Alfadda T, MacGregor GG, Dong K, Wang T, Geibel JP. Kir1.1 (ROMK) and Kv7.1 (KCNQ1/KvLQT1) are essential for normal gastric acid secretion: importance of functional Kir1.1. Pflugers Arch 2015;467:1457-1468.

23. Rotte A, Pasham V, Mack AF, et al. Ca2+ activated K+ channel Kca3.1 as a determinant of gastric acid secretion. Cell Physiol Biochem 2011;27:597-604.

24. Heitzmann D, Warth R. No potassium, no acid: $\mathrm{K}+$ channels and gastric acid secretion. Physiology (Bethesda) 2007;22:335-341.

25. Sidani SM, Kirchhoff P, Socrates T, et al. DeltaF508 mutation results in impaired gastric acid secretion. J Biol Chem 2007;282:6068-6074.

26. Xu J, Song P, Miller ML, et al. Deletion of the chloride transporter Slc26a9 causes loss of tubulovesicles in parietal cells and impairs acid secretion in the stomach. Proc Natl Acad Sci U S A 2008;105:17955-17960.

27. Fellenius E, Berglindh T, Sachs G, et al. Substituted benzimidazoles inhibit gastric acid secretion by blocking $(\mathrm{H}++\mathrm{K}+)$ ATPase. Nature 1981;290:159-161.

28. Sachs G, Shin JM, Hunt R. Novel approaches to inhibition of gas- tric acid secretion. Curr Gastroenterol Rep 2010;12:437-447.

29. Tytgat GN. Shortcomings of the first-generation proton pump inhibitors. Eur J Gastroenterol Hepatol 2001;13 Suppl 1:S29-S33.

30. Geibel JP. Role of potassium in acid secretion. World J Gastroenterol 2005; 11:5259-5265.

31. Ene MD, Khan-Daneshmend T, Roberts CJ. A study of the inhibitory effects of SCH 28080 on gastric secretion in man. Br J Pharmacol 1982;76:389-391.

32. Wurst W, Hartmann M. Current status of acid pump antagonists (reversible PPIs). Yale J Biol Med 1996;69:233-243.

33. Asano S, Matsuda S, Hoshina S, Sakamoto S, Takeguchi N. A chimeric gastric $\mathrm{H}+, \mathrm{K}+-\mathrm{ATPase}$ inhibitable with both ouabain and SCH 28080. J Biol Chem 1999;274:6848-6854.

34. Shin JM, Sachs G. Gastric H,K-ATPase as a drug target. Dig Dis Sci 2006;51:823-833.

35. Dent J, Kahrilas PJ, Hatlebakk J, et al. A randomized, comparative trial of a potassium-competitive acid blocker (AZD0865) and esomeprazole for the treatment of patients with nonerosive reflux disease. Am J Gastroenterol 2008;103:20-26.

36. Yu KS, Bae KS, Shon JH, et al. Pharmacokinetic and pharmacodynamic evaluation of a novel proton pump inhibitor, YH1885, in healthy volunteers. J Clin Pharmacol 2004;44:73-82.

37. Garnock-Jones KP. Vonoprazan: first global approval. Drugs 2015;75:439-443.

38. Sack DA, Sack RB, Nair GB, Siddique AK. Cholera. Lancet 2004;363:223-233.

39. Kliger AS, Binder HJ, Bastl C, Hayslett JP. Demonstration of active potassium transport in the mammalian colon. J Clin Invest 1981;67:1189-1196.

40. Sangan P, Rajendran VM, Mann AS, Kashgarian M, Binder HJ. Regulation of colonic H-K-ATPase in large intestine and kidney by dietary Na depletion and dietary $\mathrm{K}$ depletion. Am J Physiol 1997;272(2 Pt 1):C685-C696.

41. Codina J, DuBose TD Jr. Molecular regulation and physiology of the H+,K+: ATPases in kidney. Semin Nephrol 2006;26:345-351.

42. Meneton P, Schultheis PJ, Greeb J, et al. Increased sensitivity to $\mathrm{K}+$ deprivation in colonic $\mathrm{H}, \mathrm{K}-\mathrm{ATPase}$-deficient mice. J Clin Invest 1998;101:536-542.

43. Schroeder BC, Waldegger S, Fehr S, et al. A constitutively open potassium channel formed by KCNQ1 and KCNE3. Nature 2000;403: 196-199.

44. Pouokam E, Bader S, Brück B, Schmidt B, Diener M. ATPsensitive $\mathrm{K}(+)$ channels in rat colonic epithelium. Pflugers Arch 2013;465:865-877.

45. Foster ES, Jones WJ, Hayslett JP, Binder HJ. Role of aldosterone and dietary potassium in potassium adaptation in the distal colon of the rat. Gastroenterology 1985;88(1 Pt 1):41-46.

46. Butterfield I, Warhurst G, Jones MN, Sandle GI. Characterization of apical potassium channels induced in rat distal colon during potassium adaptation. J Physiol 1997;501(Pt 3):537-547.

47. Sausbier M, Matos JE, Sausbier U, et al. Distal colonic K(+) secretion occurs via BK channels. J Am Soc Nephrol 2006;17:1275- 
1282.

48. Barmeyer C, Rahner C, Yang Y, Sigworth FJ, Binder HJ, Rajendran VM. Cloning and identification of tissue-specific expression of KCNN4 splice variants in rat colon. Am J Physiol Cell Physiol 2010;299:C251-C263.

49. Singh SK, O’Hara B, Talukder JR, Rajendran VM. Aldosterone induces active $\mathrm{K}+$ secretion by enhancing mucosal expression of Kcnn4c and Kcnma1 channels in rat distal colon. Am J Physiol Cell Physiol 2012;302:C1353-C1360.

50. Bachmann 0, Wüchner K, Rossmann H, et al. Expression and regulation of the Na+-K+-2Cl- cotransporter NKCC1 in the normal and CFTR-deficient murine colon. J Physiol 2003;549(Pt 2):525536.

51. Sorensen MV, Matos JE, Praetorius HA, Leipziger J. Colonic potassium handling. Pflugers Arch 2010;459:645-656.

52. Sandle GI, Hunter M. Apical potassium (BK) channels and enhanced potassium secretion in human colon. QJM 2010;103:8589.

53. Sandle GI, Perry MD, Mathialahan T, et al. Altered cryptal expression of luminal potassium (BK) channels in ulcerative colitis. J Pathol 2007;212:66-73.

54. Kanthesh BM, Sandle GI, Rajendran VM. Enhanced K(+) secretion in dextran sulfate-induced colitis reflects upregulation of large conductance apical $\mathrm{K}(+)$ channels (BK; Kcnma1). Am J Physiol Cell Physiol 2013;305:C972-C980.

55. Al-Hazza A, Linley JE, Aziz Q, Maclennan KA, Hunter M, Sandle GI. Potential role of reduced basolateral potassium (IKCa3.1) channel expression in the pathogenesis of diarrhoea in ulcerative colitis. J Pathol 2012;226:463-470.

56. Wang WH. Regulation of ROMK (Kir1.1) channels: new mechanisms and aspects. Am J Physiol Renal Physiol 2006;290:F14-F19.

57. Ashby WB, Humphreys J, Smith SJ. Small-bowel ulceration induced by potassium chloride. Br Med J 1965;2:1409-1412.

58. Boley SJ, Schultz L, Krieger H, Schwartz S, Elguezabal A, Allen AC. Experimental evaluation of thiazides and potassium as a cause of small-bowel ulcer. JAMA 1965;192:763-768.

59. Leijonmarck CE, Räf L. Ulceration of the small intestine due to slow-release potassium chloride tablets. Acta Chir Scand 1985;151:273-278.

60. Laine L, Takeuchi K, Tarnawski A. Gastric mucosal defense and cytoprotection: bench to bedside. Gastroenterology 2008;135:4160.

61. Vaananen PM, Keenan CM, Grisham MB, Wallace JL. Pharmacological investigation of the role of leukotrienes in the pathogenesis of experimental NSAID gastropathy. Inflammation 1992;16:227240.

62. Santucci L, Fiorucci S, Giansanti M, Brunori PM, Di Matteo FM, Morelli A. Pentoxifylline prevents indomethacin induced acute gastric mucosal damage in rats: role of tumour necrosis factor alpha. Gut 1994;35:909-915.

63. Lichtenberger LM. Where is the evidence that cyclooxygenase inhibition is the primary cause of nonsteroidal anti-inflammatory drug (NSAID)-induced gastrointestinal injury? Topical injury revisited. Biochem Pharmacol 2001;61:631-637.

64. Tomisato W, Tanaka K, Katsu T, et al. Membrane permeabilization by non-steroidal anti-inflammatory drugs. Biochem Biophys Res Commun 2004;323:1032-1039.

65. Ocaña M, Cendán CM, Cobos EJ, Entrena JM, Baeyens JM. Potassium channels and pain: present realities and future opportunities. Eur J Pharmacol 2004;500:203-219.

66. Frolov RV, Singh S. Celecoxib and ion channels: a story of unexpected discoveries. Eur J Pharmacol 2014;730:61-71.

67. Markham A, Plosker GL, Goa KL. Nicorandil. An updated review of its use in ischaemic heart disease with emphasis on its cardioprotective effects. Drugs 2000;60:955-974.

68. Guth PH. Current concepts in gastric microcirculatory pathophysiology. Yale J Biol Med 1992;65:677-688.

69. Scully C, Azul AM, Crighton A, Felix D, Field A, Porter SR. Nicorandil can induce severe oral ulceration. Oral Surg Oral Med Oral Pathol Oral Radiol Endod 2001;91:189-193.

70. Katory M, Davies B, Kelty C, et al. Nicorandil and idiopathic anal ulceration. Dis Colon Rectum 2005;48:1442-1446.

71. Egred M, Andron M, Morrison WL. Nicorandil may be associated with gastrointestinal ulceration. BMJ 2006;332:889.

72. Brown R, Lee A, Welfare M. Nicorandil-induced colonic ulceration. Heart 2008;94:678.

73. Skellett AM, Cullen P, Dootson G. Peristomal ulceration caused by nicorandil. Clin Exp Dermatol 2009;34:87-88.

74. El-Dars LD, Bhagwanadas K, Hemmadi S, Hughes J. Nicorandil associated vulval and inguinal ulceration. J Obstet Gynaecol 2009;29:674-675

75. Lee CC, Chang SS, Lee SH, Chen YS, Hsu WT, Gabriel Lee MT. Use of nicorandil is associated with increased risk for gastrointestinal ulceration and perforation: a nationally representative populationbased study. Sci Rep 2015;5:11495.

76. Patel HM, Santani DD, Goswami SG. Evaluation of the effects of nicorandil on experimentally induced gastric ulcers. Pharmacology 2001;63:154-159.

77. Rahgozar M, Pazokitoroudi H, Bakhtiarian A, Djahanguiri B. Diazoxide, a K(ATP) opener, accelerates restitution of ethanol or indomethacin-induced gastric ulceration in rats independent of polyamines. J Gastroenterol Hepatol 2001;16:290-296.

78. Simon M, Duong JP, Mallet V, et al. Over-expression of colonic $\mathrm{K}+$ channels associated with severe potassium secretory diarrhoea after haemorrhagic shock. Nephrol Dial Transplant 2008;23:33503352.

79. Matos JE, Sausbier M, Beranek G, Sausbier U, Ruth P, Leipziger J. Role of cholinergic-activated KCa1.1 (BK), KCa3.1 (SK4) and KV7.1 (KCNQ1) channels in mouse colonic Cl- secretion. Acta Physiol (Oxf) 2007;189:251-258.

80. Thompson-Vest N, Shimizu Y, Hunne B, Furness JB. The distribution of intermediate-conductance, calcium-activated, potassium (IK) channels in epithelial cells. J Anat 2006;208:219-229.

81. Dvoryanchikov G, Sinclair MS, Perea-Martinez I, Wang T, 
Chaudhari N. Inward rectifier channel, ROMK, is localized to the apical tips of glial-like cells in mouse taste buds. J Comp Neurol 2009;517:1-14.

82. Nakamura N, Suzuki Y, Sakuta H, Ookata K, Kawahara K, Hirose S. Inwardly rectifying $\mathrm{K}+$ channel Kir7.1 is highly expressed in thyroid follicular cells, intestinal epithelial cells and choroid plexus epithelial cells: implication for a functional coupling with $\mathrm{Na}+\mathrm{K}+-$ ATPase. Biochem J 1999;342(Pt 2):329-336.

83. Wu WK, Li GR, Wong HP, et al. Involvement of Kv1.1 and Nav1.5 in proliferation of gastric epithelial cells. J Cell Physiol 2006;207:437-444.

84. Rao JN, Platoshyn O, Li L, et al. Activation of $\mathrm{K}(+)$ channels and increased migration of differentiated intestinal epithelial cells after wounding. Am J Physiol Cell Physiol 2002;282:C885-C898.

85. Freeman LC, Narvaez DF, McCoy A, et al. Depolarization and decreased surface expression of $\mathrm{K}+$ channels contribute to NSAID-inhibition of intestinal restitution. Biochem Pharmacol 2007;74:74-85.

86. Shao XD, Wu KC, Hao ZM, Hong L, Zhang J, Fan DM. The potent inhibitory effects of cisapride, a specific blocker for human ethera-go-go-related gene (HERG) channel, on gastric cancer cells. Cancer Biol Ther 2005;4:295-301.

87. Lastraioli E, Guasti L, Crociani 0, et al. herg1 gene and HERG1 protein are overexpressed in colorectal cancers and regulate cell invasion of tumor cells. Cancer Res 2004;64:606-611. 